\section{JURNAL EKONOMI EFEKTIF}

ISSN : $2622-8882$, E-ISSN : 2622-9935

Jurnal Ekonomi Efektif, Vol. 3, No. 4, Juli 2021

@ Prodi Manajemen Fakultas Ekonomi Universitas

Pamulang

\title{
PENGARUH KUALITAS PELAYANAN DAN CITRA PERUSAHAAN TERHADAP KEPUASAN NASABAH PADA PT. BANK DANAMON TBK CABANG BINTARO
}

\author{
Triyadi $^{1 *}$, Rizka Wahyuni Amelia ${ }^{2}$, Abdul Khoir ${ }^{3}$ \\ Universitas Pamulang, Tangerang Selatan, Banten, Indonesia \\ dosen02488@unpam.ac.id**
}

Manuskrip: Mei -2021 Ditinjau: Juni -2021; Diterima: Juni-2021; Online: Juli-2021; Diterbitkan: Juli-2021

\begin{abstract}
ABSTRAK
Penelitian ini bertujuan untuk mengetahui pengaruh kualitas pelayanan dan citra perusahaan terhadap kepuasan nasabah pada PT. Bank Danamon, Tbk. Cabang Bintaro. Metode yang digunakan adalah explanatory research dengan teknik analisis menggunakan analisis statistik dengan pengujian regresi, korelasi, determinasi dan uji hipotesis. Hasil penelitian ini kualitas pelayanan berpengaruh signifikan terhadap kepuasan nasabah sebesar $52,9 \%$, uji hipotesis diperoleh $\mathrm{t}$ hitung $>\mathrm{t}$ tabel atau $(9,721>1,989)$. Citra perusahaan berpengaruh signifikan terhadap kepuasan nasabah sebesar 38,6\%, uji hipotesis diperoleh $\mathrm{t}$ hitung $>\mathrm{t}$ tabel atau $(7,267>1,989)$. Kualitas pelayanan dan citra perusahaan secara simultan berpengaruh signifikan terhadap kepuasan nasabah dengan persamaan regresi $\mathrm{Y}=8,095+$ 0,497X1 + 0,302X2 dan kontribusi pengaruh sebesar 59,2\%, uji hipotesis diperoleh F hitung > F tabel atau $(60,093>2,710)$.
\end{abstract}

Kata Kunci: Kualitas Pelayanan, Citra Perusahaan, Kepuasan Nasabah

\begin{abstract}
This study aims to determine the effect of service quality and corporate image on customer satisfaction at PT. Bank Danamon, Tbk. Bintaro branch. The method used is explanatory research with analytical techniques using statistical analysis with regression, correlation, determination and hypothesis testing. The results of this study that service quality has a significant effect on customer satisfaction by 52.9\%, hypothesis testing is obtained t count $>$ t table or $(9,721>1,989)$. Company image has a significant effect on customer satisfaction by $38.6 \%$, hypothesis testing is obtained t count > t table or $(7.267>1.989)$. Service quality and corporate image simultaneously have a significant effect on customer satisfaction with the regression equation $Y=8.095+0.497 X 1+0.302 X 2$ and the contribution of the influence is $59.2 \%$, hypothesis testing is obtained $F$ count $>F$ table or $(60.093>2.710)$.
\end{abstract}

Keywords: Service Quality, Company Image, Customer Satisfaction 


\section{PENDAHULUAN}

\section{A. Latar Belakang}

Perkembangan dunia usaha terus mengalami pertumbuhan yang pesat, hal ini menyebabkan persaingan di antara para pelaku usaha juga semakin kompetitif. Semakin ketatnya persaingan bisnis di dunia usaha menuntut manajemen perusahaan bekerja lebih efisien dan lebih efektif untuk selalu menjaga kondisi perusahaan agar tetap bertahan dan berkembang dengan baik sehingga mempunyai kemampuan untuk mendapatkan laba, yang berarti kemampuan dalam menjual produk dengan memperoleh keuntungan. Perusahaan harus mampu memberikan apa yang menjadi kebutuhan pasar. Seperti yang diampaikan Kolter dan Armstrong (2017:55) yang menyampaikan bahwa sebuah perusahaan harus berusaha keras untuk mempelajari dan memahami kebutuhan, keiginan dan permintaan Nasabahnya. Dengan memahami kebutuhan, keinginan dan permintaan Nasabah, maka akan memberikan masukan penting bagi perusahaan untuk merancang strategy pemasaran agar dapat menciptakan kepuasan bagi penlanggannya.

Tidak hanya pada sektor industri produk, di bidang industri jasa juga dituntut dapat menyelenggarakan proses pengadaan jasa dan pelayanan yang prima dengan ditunjang oleh kemampuan pemasar yang handal sehingga kebijakan dan pencapaian tujuan organisasi dapat dicapai dengan maksimal. Dalam dunia perbankan, bisnis disektor lembaga keuangan telah dijamin dalam Undang-Undang Dasar Negara Republik Indonesia Tahun 1945 dalam Alinea ke empat Pembukaan UUD 1945 yang menyebutkan bahwa "melindungi segenap bangsa dan seluruh tumpah darah Indonesia". Secara teoritis, aline ke empat pembukaan UUD 1945 telah menentukan suatu teori perlindungan hukum bagi segenap bangsa Indonesia/warga negara dibidang ekonomi termasuk perlindungan hak nasabah perbankan. Pengertian bank menurut UndangUndang Perbankan UU No.10 tahun 1998 Pasal 1 adalah badan usaha yang menghimpun dana dari masyarakat dalam bentuk simpanan dan menyalurkan kepada masyarakat dalam rangka meningkatkan taraf hidup. Oleh karenanya dalam Undang-Undang tersebut secara jelas memberikan perlindungan kepada nasabahnya.

Dengan diberlakukan perdagangan bebas semua pelaku bisnis tidak terkecuali PT. Bank Danamon terus memperkuat pangsa pasar dalam negeri sebagai salah satu langkah menghadapi persaingan dalam Masyarakat Ekonomi ASEAN (MEA). Hal itu karena kuatnya pertumbuhan perbankan dalam negeri. Pemerintah sendiri telah menerbitkan aturan (Keputusan Presiden) No.37/2014 yang memuat banyak indikator yang harus dicapai dalam upaya untuk meningkatkan daya saing nasional dan menghadapi MEA yang sudah dimulai 2015 itu. Dengan diterbitkan inpres No.6/2014, tentang peningkatan daya saing menghadapi Masyarakat Ekonomi Asean, pemerintah Indonesia sudah menyiapkan pengembangan sektor industri, agar bisa bersaing di pasar bebas ASEAN itu. Sebut saja upaya pengembangan industri perbankan yang masuk dalam 10 pengembangan industri yang harus diantar kegerbang pasar bebas dengan semua keunggulannya.

Guna menyelaraskan visi dan misi, PT. Bank Danamon telah bertekad untuk menjadi lembaga keuangan terkemuka di Indonesia yang keberadaannya diperhitungkan. Danamon bertujuan mencapai posisi ini dengan menjadi lembaga yang berpusat pada nasabah yang melayani semua segmen, dengan menawarkan nilai yang unik untuk masing-masing segmen berdasarkan keunggulan pelayanan yang didukung oleh teknologi. Sejalan dengan upaya ini, Danamon beraspirasi menjadi bank pilihan untuk berkarya dan dihormati oleh semua pihak pemangku kepentingan serta memegang teguh kelima nilai perusahaan yaitu: peduli, jujur, mengupayakan yang terbaik, kerjasama, dan profesionalisme. Perusahaan harus terus berusaha memberikan pelayanan yang terbaik 
kepada nasabah di segmen pasar yang digeluti dengan tetap konsisten memfokuskan pada pelayanan kepada masyarakat.

Membangun dan mengembangkan bisnis perbankan memiliki tantangan tersendiri dari bisnis jenis lain. Dengan semakin majunya perkembangan teknologi dan pemahaman bisnis dikalangan masyarakat, menuntut perusahaan harus memperkuat pelayanan guna memenangkan tingkat persaingan yang sekarang ini relatif ketat dengan cukup memiliki kemampuan agar perusahaan berhasil secara kompetitif mampu memenuhi kebutuhan konsumen dan peningkatan pelayanan, karena dengan pelayanan yang baik maka Nasabah akan merasakan puas.

Menurut Laksana (2017:66) "Pelayanan adalah setiap tindakan atau kegiatan yang dapat di tawarkan kepada pihak lain, yang pada dasarnya tidak berwujud dan tidak mengakibatkan kepemilikan apapun". Melihat kondisi tersebut, pada saat ini para industri berusaha memberikan kualitas pelayanan yang baik untuk menarik konsumen, maka dari itu kunci sukses bagi perusahaan jasa adalah pelayanan jasa yang baik dan tersedianya produk jasa yang dibutuhkan Nasabah juga peningkatan kualitas pelayanan baik.

Tindakan yang harus di prioritaskan oleh perusahaan dalam pasar bebas ini adalah kepuasan nasabah, dimana menurut Kotler (2017:45) ialah "Perasaan senang atau kecewa seseorang yang muncul setelah membandingkan antara persepsi atau kesannya terhadap kinerja atau hasil suatu produk atau jasa atas terpenuhi atau tidak harapan-harapannya".

Seiring dengan terus berkembangnya perusahaan dan untuk lebih menampilkan citra positif perusahaan, maka manajemen Bank Danamon Indonesia yang sejarah awalnya terbentuk Bank Danamon Indonesia pada tahun 1956 awalnya bernama PT. Bank Kopra Indonesia.Bank Danamon telah berulang kali berganti nama. Setelah berganti nama, untuk pertama kali yang mempelopori pertukaran mata uang asing di Indonesia.

Menurut Kotler (2017:86) berpendapat bahwa meningkatkan kepuasan Nasabah menjadi modal utama bagi organisasi untuk memperkecil resiko dalam kelangsungan hidup organisasi. Setiap organisasi perbankan harus menyusun strategi dalam mewujudkan kepuasan nasabah. Strategi organisasi yang harus dipilih atau dirancang tentu yang terkait dengan faktor-faktor yang mempengaruhi kepuasan nasabah. Kualitas kepuasan dalam suatu organisasi merupakan refleksi dari kualitas pelayanan yang diberikan oleh organisasi tersebut.

Dengan semakin banyaknya bank lain yang memberikan penawaran produk dan jasa, harus disikapi oleh perusahaan dengan melakukan strategi pemasaran yang tepat guna meningkiatkan profit sehingga mencapai akseptasi target yang ditentukan, ini menunjukkan bahwa banyak variabel yang harus dibenahi agar kinerja pemasaran perusahaan dapat tercapai dan mampu bersaing dalam membuka pasar yang baru. Sekarang ini semakin banyak pilihan produk jasa membuat nasabah memiliki banyak pilihan sehingga bank dapat memperluas pangsa pasarnya, Keberhasilan perusahaan dalam menjaring Nasabah tercermin dari banyaknya nasabah baik itu perorangan maupun perusahaanBerikut jumlah Nasabah PT. Bank Danamon Tbk Cabang Bintaro, seperti dalam tabel berikut:

Tabel 1. Jumlah Nasabah Bank Danamon Cabang Bintaro Tahun 2015-2019

\begin{tabular}{|c|c|c|c|c|}
\hline \multirow{2}{*}{ Tahun } & \multicolumn{2}{|c|}{ Jumlah Nasabah Bank Danamon } & \multirow{2}{*}{ Keterangan } \\
\cline { 2 - 4 } & \multirow{2}{*}{ Jumlah Nasabah } & \multicolumn{2}{|c|}{ Perkembangan } & \\
\cline { 3 - 4 } & & Penambahan & $(\%)$ & \\
\hline 2015 & 513 & - & - & Naik \\
\hline 2016 & 526 & 13 & $2,53 \%$ & Naik \\
\hline 2017 & 605 & 79 & $15,02 \%$ & \multirow{2}{*}{} \\
\hline
\end{tabular}




\begin{tabular}{|l|l|l|l|l|}
\hline 2018 & 650 & 45 & $7,44 \%$ & Naik \\
\hline 2019 & 610 & -40 & $-6,15 \%$ & Naik \\
\hline
\end{tabular}

Sumber: PT. Bank Danamon Tbk Cabang Bintaro, 2020

Jumlah nasabah perusahaan setiap tahun mengalami perkembangan yang fluktuatif. Perkembangan dalam data tabel tersebut di atas apabila dibuat grafik maka akan terlihat sebagai berikut:

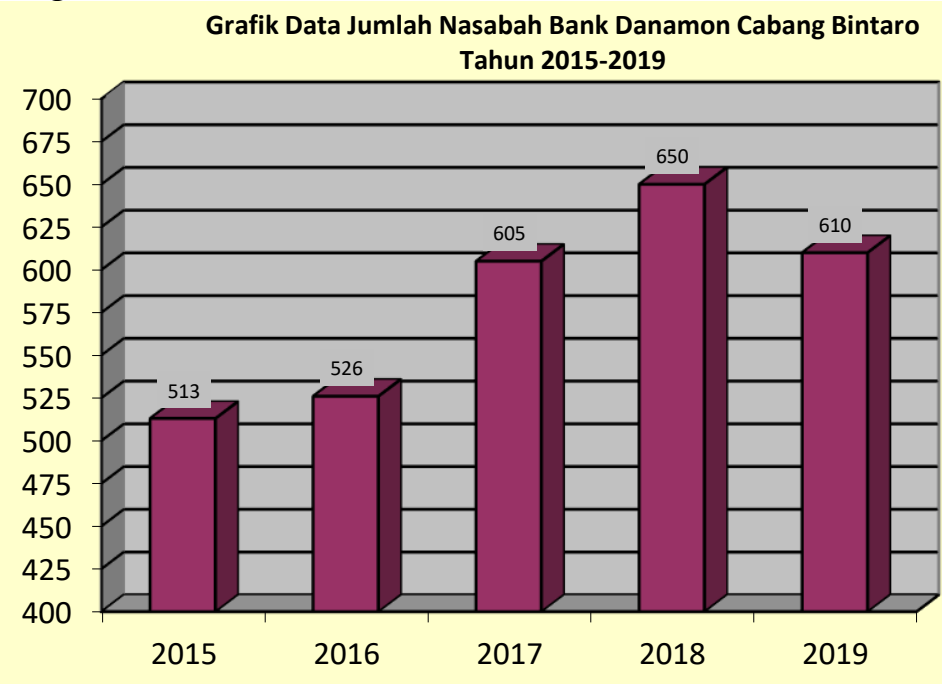

Sumber: PT. Bank Danamon Tbk Cabang Bintaro (diolah), 2020

Gambar 1. Grafik Perkembangan Jumlah Nasabah Tahun 2015-2019

Berdasarkan Tabel data 2 dan gambar grafik 1. di atas jumlah nasabah PT. Bank Danamon Tbk Cabang Bintaro berfluktuatif dengan prosentase penurunan dan penambahan yang berbeda-beda. Secara keseluruhan dari tahun 2015-2019 jumlah nasabah rata-rata per tahun hanya 580 nasabah dengan penambahan per tahun sebesar 24 nasabah atau hanya mengalami penambahan sebesar $4,71 \%$. Kondisi seperti ini jelas kurang baik manakala dibandingkan dengan perkembangan dunia bisnis yang saat ini sudah sangat bergantung pada dunia digital elektronik dan pembayaran transaksi melalui bank. Adanya beberapa nasabah yang beralih ke bank pesaing (competitor) harus disikapi dengan bijak dan memerlukan terobosan inovasi pelayanan yang baik karena itu melihat trend yang cenderung turun maka upaya peningkatan kualitas pelayanan harus segera diperbaiki agar harapan Nasabah dapat dipenuhi.

Hasil pra-riset yang penulis lakukan telah di temukan beberapa gejala masalah, diantaranya: pelayanan yang ada masih banyak kekurangan, masih banyaknya nasabah yang belum puas, keinginan dan kebutuhan nasabah kurang menjadi prioritas pelayanan kemudian dalam upaya mmenjaring nasabah baru sering terhambat adanya faktor penerapan komunikasi yang terjalin tidak optimal sehingga sering terjadi informasi yang tidak tepat. Kemampuan perusahaan dalam memberikan pelayanan kepada nasabah dapat menjadi salah satu faktor yang turut memberikan kontribusi positif bagi perusahaan. Tingginya tingkat persaingan direfleksikan dengan semakin sensitifnya tuntutan nasabah memiliki resiko kegagalan dalam bisnis. Selama ini evaluasi kinerja pemasaran yang dimiliki perusahaan untuk membangun kepuasan nasabah dirasakan masih sangat kurang. Berikut ini jumlah keluhan nasabah selama tahun 2015-2019 sesuai data tabel dibawah ini: 
Tabel 2. Jumlah Keluhan Nasabah Bank Danamon Cabang Bintaro Tahun 2015- 2019

\begin{tabular}{|c|c|c|c|c|}
\hline \multirow{2}{*}{ Jenis Komplain Nasabah } & \multicolumn{4}{|c|}{ Tahun dan Jumlah Komplain } \\
\cline { 2 - 5 } & 2015 & 2017 & 2018 & 2019 \\
\hline Penyampaian informasi kurang akurat & 24 & 28 & 31 & 35 \\
\hline Prioritas pelayanan nasabah lambat & 25 & 27 & 22 & 29 \\
\hline Sarana prasarana kurang memadahi & 11 & 13 & 15 & 14 \\
\hline Adanya produk jasa yang tidak sesuai & 12 & 16 & 19 & 21 \\
\hline Keterlambatan respon petugas bank & 23 & 28 & 31 & 34 \\
\hline Garansi tidak sesuai dengan perjanjian & 14 & 8 & 12 & 15 \\
\hline Prosedur transaksi tidak simple & 6 & 9 & 10 & 10 \\
\hline Jumnlah & $\mathbf{1 1 5}$ & $\mathbf{1 2 9}$ & $\mathbf{1 4 0}$ & $\mathbf{1 5 8}$ \\
\hline
\end{tabular}

Sumber:Data PT. Bank Danamon Tbk Cabang Bintaro, 2020

Adanya peningkatan jumlah komplain dari nasabah seperti pada tabel di atas mengenai penyampaian informasi yang kurang akurat, prioritas pelayanan nasabah, sarana prasarana yang kurang memadahi, produk jasa yang kurang sesuai, respon kurang cepat, garansi tidak sesuai dengan yang diperjanjikan dan prosedur transaksi kurang simpel menjadikan beberapa nasabah beralih kurang puas. Kesusksesan perusahaan banyak ditentukan oleh prestasi bidang pemasaran dimana pemasar harus dapat memenuhi kebutuhan dan keinginan nasabah yang dapat memuaskan nasabah. Seperti yang disampaikan oleh Fandy Tjiptono (2017:87) bahwa dalam tujuan suatu bisnis penting perusahaan menciptakan konsumen merasa puas, karena kualitas jasa yang unggul dan konsisten dapat menumbuhkan kepuasan Nasabah dan dapat memberikan manfaat. Hal ini juga selaras dengan pendapat Rangkuti (2015:12) dimana kepuasan Nasabah dipengaruhi oleh persepsi kualitas jasa, kualitas produk dan faktor lain yang berfokus pada lima dimensi yaitu tangibles, reliability, responsiveness, assurance dan empathy.

Kepuasan Nasabah memegang peranan penting dalam perusahaan. Menurut Ferrinadewi (2016:97) mengartikan kepuasan nasabah sebagai evaluasi dari keseluruhan kinerja yang diberikan perusahaan dalam memberikan pelayanan, memenuhi harapan dan keinginan Nasabah. Selaras dengan pendapat tersebut menurut Kotler (2017:58) berpendapat kepuasan pelanggan adalah perasaan (feeling) yang dirasakan pembeli dari kinerja perusahaan yang memenuhi harapan mereka.

Citra dibangun oleh apa yang konsumen atau masyarakat rasakan dan ketahui mengenai perusahaan, berdasar pada informasi dari mulut ke mulut dari konsumen serta pengalaman pribadi, informasi yang diterima dari orang lain, serta promosi yang dilakukan oleh perusahaan. Adreassen \& Lindestad (2016:12) juga mengungkapkan bahwa citra suatu perusahaan ditentukan oleh bagaimana inteprestasi mengenai yang diproyeksikan dari identitas perusahaan, yang membentuk keseluruhan kesan dalam pikiran konsumen.

Berikut ini peringkat Bank terbaik dengan dalam kriteria Bank Umum Swasta Nasional Devisa tahun 2019 dalam tabel sebagai berikut.

Tabel 3. Peringkat Bank Umum Swasta Nasional Devisa Tahun 2019

\begin{tabular}{|c|c|l|}
\hline Rangking & Nama Bank & Kategory \\
\hline 1 & PT. Bank Bukopin & Excellent Financial Performance \\
\hline 2 & PT. Bank Bumi Arta. & Excellent Financial Performance \\
\hline 3 & PT. Bank Capital Indonesia & Excellent Financial Performance \\
\hline 4 & PT. Bank Central Asia & Excellent Financial Performance \\
\hline 5 & PT. Bank Danamon Indonesia & Excellent Financial Performance \\
\hline 6 & PT. Bank ICBT & Excellent Financial Performance \\
\hline 7 & PT. Bank Maspion & Excellent Financial Performance \\
\hline 8 & PT. Bank Mayapada & Excellent Financial Performance \\
\hline
\end{tabular}




\begin{tabular}{|c|c|c|}
\hline 9 & PT. Bank Maybank Indonesia & Excellent Financial Performance \\
\hline 10 & PT. Bank Mayora & Excellent Financial Performance \\
\hline
\end{tabular}

Sumber : PT. Bank Danamon, 2020

Berdasarkan data di atas, hasil riset Warta Ekonomi ini menghasilkan Banking Brand Award 2019 bank-bank terbaik berdasarkan persepsi masyarakat berdasar aspek keuangan, dimana PT. Bank Danamon masih menempati peringkat ke lima. Kondisi ini menurun satu peringkat jika dibandingkan dengan tahun 2018 yang menempati peringkat ke empat.

Dalam upaya meningkatkan pelayanan kepada nasabah, perusahaan harus menciptakan standar pelayanan yang edukatif yang mempunyai pedoman perilaku dan memberikan edukasi bagi karyawan setiap divisinya dalam menghadapi nasabah sehingga tercipta pelayanan yang terbaik, proaktif, layanan secara tuntas dan optimal bagi nasabah sehingga menimbulkan kesan excellence, selain itu menciptakan images yang baik pada nasabah serta memperhatikan kebutuhan nasabah secara komperhensif. Kotler dan Amstrong (2017:583) menyampaikan bahwa kualitas pelayanan berpengaruh terhadap kepuasan konsumen, selain itu juga dapat menciptakan keuntungan. Semakin tinggi kualitas pelayanan maka semakin tinggi pula kepuasan yang diperoleh Nasabah.

Kondisi riil di atas menggambarkan bahwa pelayanan yang diberikan oleh perusahaan saat ini masih kurang optimal. Hal tersebut dapat mengakibatkan menurunnya tingkat kepuasan dari nasabah. Menunjuk pada kondisi yang dikemukakan di atas maka penulis tertarik untuk melakukan penelitian dengan judul "Pengaruh Kualitas Pelayanan Dan Citra Perusahaan Terhadap Kepuasan Nasabah Pada PT. Bank Danamon Tbk Cabang Bintaro".

\section{B. Rumusan Masalah}

1. Adakah pengaruh antara kualitas pelayanan terhadap kepuasan nasabah pada PT. Bank Danamon, Tbk. Cabang Bintaro ?

2. Adakah pengaruh antara citra perusahaan terhadap kepuasan nasabah pada PT. Bank Danamon, Tbk. Cabang Bintaro?

3. Adakah pengaruh secara simultan antara kualitas pelayanan dan citra perusahaan terhadap kepuasan nasabah pada PT. Bank Danamon, Tbk. Cabang Bintaro ?

\section{Tujuan Penelitian}

1. Untuk mengetahui pengaruh kualitas pelayanan terhadap kepuasan nasabah pada PT. Bank Danamon, Tbk. Cabang Bintaro.

2. Untuk mengetahui pengaruh citra perusahaan terhadap kepuasan nasabah pada PT. Bank Danamon, Tbk. Cabang Bintaro.

3. Untuk mengetahui pengaruh secara simultan antara kualitas pelayanan dan citra perusahaan terhadap kepuasan nasabah pada PT. Bank Danamon, Tbk. Cabang Bintaro.

\section{TINJAUAN PUSTAKA}

\section{Kualitas Pelayanan}

Yang kualitas pelayanan dalam penelitian ini adalah pelayanan yang didapat oleh konsumen dalam memenuhi keinginan dan kebutuhannya. (Tjiptono, 2017:236). Adapun indikator yang digunakan meliputi: 1) Bukti fisik (Tangible), 2) Kehandalan (Reliability), 3) Respoonsif (Responsiveness), 4) Jaminan (Assueance), 5) Empati (Empathy). 


\section{Citra Perusahaan}

Yang dimaksud citra perusahaan dalam penelitian ini adalah kesan secara umum yang teritinggal dibenak pelanggan sebagai dari hasil kumpulan perasaan, ide, sikap dan pengalaman dengan perusahaan yang disimpan dalam ingatan (Fandy Tjiptono, 2017:245). Adapun indikator yang dapat digunakan meliputi: 1. Disukai (Likeability), 2. Kompetensi (Competence), 3. Kualitas (Quality). 4. Kinerja (Performance). 5. Tanggung jawab (Responsibility).

\section{Kepuasan nasabah}

Dalam penelitian ini yang dijadikan variabel dependen adalah kepuasan pelanggan yang diartikan sebagai perasaan yang dirasakan oleh pelanggan sebagai akibat dari terpenuhinya harapan dan keinginan atas produk yang dibelinya serta dapat memiliki manfaat yang tepat (Kotler dan Keller, 2017:138). Adapun indikator yang dapat digunakan meliputi: a) memenuhi harapan, b) memenuhi kebutuhan, c) setia pada produk yang dihasilkan perusahaan, d) merekomendasikan, e) menawarkan ide/gagasan yang baik.

\section{METODE PENELITIAN}

\section{Populasi}

Populasi dalam penelitian ini berjumlah 86 responden PT. Bank Danamon, Tbk. Cabang Bintaro

\section{Sampel}

Sampel dalam penelitian ini berjumlah 86 responden.

\section{Jenis Penelitian}

Jenis penelitian yang dipakai adalah kuantitatif, dimana tujuannya adalah untuk mengetahui pengaruh antara variabel bebas terhadap variabel terikat baik parsial maupun simultan

\section{Metode Analisis Data}

Dalam menganalisis data digunakan uji instrumen, uji asumsi klasik, regresi, koefisien korelasi, koefisien determinasi dan uji hipotesis.

\section{HASIL PENELITIAN}

\section{Analisis Deskriptif}

Pada pengujian ini digunakan untuk mengetahui skor minimum dan maksimum, mean score dan standar deviasi dari masing-masing variabel. Adapun hasilnya sebagai berikut:

Tabel 4. Hasil Analisis Descriptive Statistics

Descriptive Statistics

\begin{tabular}{l|r|r|r|r|r} 
& \multicolumn{7}{c}{ Descriptive Statistics } \\
& N & Minimum & Maximum & Mean & Std. Deviation \\
\hline Kualitas Pelayanan (X1) & 86 & 30 & 47 & 37.93 & 4.253 \\
\hline Citra Perusahaan (X2) & 86 & 29 & 46 & 37.44 & 3.849 \\
\hline Kepuasan Nasabah (Y) & 86 & 30 & 47 & 38.23 & 3.818 \\
\hline Valid N (listwise) & 86 & & & & \\
\hline
\end{tabular}

Kualitas pelayanan diperoleh varians minimum sebesar 30 dan varians maximum

47 dengan mean score sebesar 37,93 dengan standar deviasi 4,253.

Citra perusahaan diperoleh varians minimum sebesar 29 dan varians maximum 46 dengan mean score sebesar 37,44 dengan standar deviasi 3,849.

Kepuasan nasabah diperoleh varians minimum sebesar 30 dan varians maximum 47 dengan mean score sebesar 38,23 dengan standar deviasi 3,818. 


\section{Analisis Verifikatif}

Pada analisis ini dimaksudkan untuk mengetahui pengaruh variabel independen terhadap variabel dependen. Adapun hasil pengujian sebagai berikut:

\section{a. Analisis Regresi Linier Berganda}

Uji regresi ini dimaksudkan untuk mengetahui perubahan variabel dependen jika variabel independen mengalami perubahan. Adapun hasil pengujiannya sebagai berikut:

\begin{tabular}{|c|c|c|c|c|c|c|}
\hline \multirow{3}{*}{\multicolumn{2}{|c|}{ Model }} & \multicolumn{3}{|c|}{ Coefficients $^{a}$} & \multirow[b]{3}{*}{$\mathrm{t}$} & \multirow[b]{3}{*}{ Sig. } \\
\hline & & \multicolumn{2}{|c|}{$\begin{array}{l}\text { Unstandardized } \\
\text { Coefficients }\end{array}$} & \multirow{2}{*}{$\begin{array}{c}\text { Standardized } \\
\text { Coefficients } \\
\text { Beta }\end{array}$} & & \\
\hline & & $\mathrm{B}$ & Std. Error & & & \\
\hline 1 & (Constant) & 8.095 & 2.838 & & 2.852 & .005 \\
\hline & Kualitas Pelayanan (X1) & .497 & .077 & .553 & 6.462 & .000 \\
\hline & Citra Perusahaan (X2) & .302 & .085 & .304 & 3.553 & .001 \\
\hline
\end{tabular}

a. Dependent Variable: Kepuasan Nasabah (Y)

Berdasarkan hasil pengujian pada tabel di atas, diperoleh persamaan regresi $\mathrm{Y}$ $=8,095+0,497 \mathrm{X} 1+0,302 \mathrm{X} 2$. Dari persamaan tersebut dijelaskan sebagai berikut:

1) Konstanta sebesar 8,095 diartikan jika kualitas pelayanan dan citra perusahaan tidak ada, maka telah terdapat nilai kepuasan nasabah sebesar 8,095 point.

2) Koefisien regresi kualitas pelayanan sebesar 0,497 , angka ini positif artinya setiap ada peningkatan kualitas pelayanan sebesar 0,497 maka kepuasan nasabah juga akan mengalami peningkatan sebesar 0,497 point.

3) Koefisien regresi citra perusahaan sebesar 0,302, angka ini positif artinya setiap ada peningkatan citra perusahaan sebesar 0,302 maka kepuasan nasabah juga akan mengalami peningkatan sebesar 0,302 point.

\section{b. Analisis Koefisien Korelasi}

Analisis koefisien korelasi dimaksudkan untuk mengetahui tingkt kekuatan hubungan dari variabel independen terhadap variabel dependen baik secara parsial maupun simultan. Adapun hasil pengujian sebagai berikut:

Tabel 6. Hasil Pengujian Koefisien Korelasi Kualitas pelayanan Terhadap Kepuasan nasabah.

Correlations $^{\mathbf{b}}$

\begin{tabular}{llr|r} 
& & \multicolumn{1}{c}{$\begin{array}{c}\text { Kualitas } \\
\text { Pelayanan (X1) }\end{array}$} & $\begin{array}{c}\text { Kepuasan } \\
\text { Nasabah (Y) }\end{array}$ \\
\hline Kualitas Pelayanan (X1) & Pearson Correlation & 1 & $.728^{* *}$ \\
\cline { 2 - 4 } & Sig. (2-tailed) & $.728^{* *}$ & .000 \\
\hline Kepuasan Nasabah (Y) & Pearson Correlation & .000 & 1 \\
\cline { 2 - 4 } & Sig. (2-tailed) & & \\
\hline
\end{tabular}

**. Correlation is significant at the 0.01 level (2-tailed).

b. Listwise $\mathrm{N}=86$

Berdasarkan hasil pengujian diperoleh nilai korelasi sebesar 0,728 artinya kualitas pelayanan memiliki hubungan yang kuat terhadap kepuasan nasabah.

Tabel 7. Hasil Pengujian Koefisien Korelasi Citra perusahaan Terhadap Kepuasan nasabah.

\begin{tabular}{llrr} 
& \multicolumn{1}{c}{ Correlations $^{\mathbf{b}}$} & $\begin{array}{c}\text { Citra Perusahaan } \\
(\mathrm{X} 2)\end{array}$ & \multicolumn{1}{c}{$\begin{array}{c}\text { Kepuasan } \\
\text { Nasabah (Y) }\end{array}$} \\
\hline Citra Perusahaan (X2) & Pearson Correlation & 1 & $.621^{* *}$ \\
\cline { 2 - 4 } & Sig. (2-tailed) & & .000 \\
\hline Kepuasan Nasabah (Y) & Pearson Correlation & $.621^{* *}$ & 1 \\
\hline
\end{tabular}




\section{Sig. (2-tailed)}

.000

**. Correlation is significant at the 0.01 level (2-tailed).

b. Listwise $\mathrm{N}=86$

Berdasarkan hasil pengujian diperoleh nilai korelasi sebesar 0,621 artinya citra perusahaan memiliki hubungan yang kuat terhadap kepuasan nasabah.

Tabel 8. Hasil Pengujian Koefisien Korelasi Kualitas pelayanan dan Citra perusahaan secara simultan Terhadap Kepuasan nasabah.

\section{Model Summary}

\begin{tabular}{|c|c|c|c|c|}
\hline Model & $\mathrm{R}$ & R Square & $\begin{array}{l}\text { Adjusted R } \\
\text { Square }\end{array}$ & $\begin{array}{l}\text { Std. Error of the } \\
\text { Estimate }\end{array}$ \\
\hline 1 & $.769^{\mathrm{a}}$ & .592 & .582 & 2.470 \\
\hline
\end{tabular}

a. Predictors: (Constant), Citra Perusahaan (X2), Kualitas Pelayanan (X1)

Berdasarkan hasil pengujian diperoleh nilai korelasi sebesar 0,769 artinya kualitas pelayanan dan citra perusahaan secara simultan memiliki hubungan yang kuat terhadap kepuasan nasabah.

\section{c. Analisis Koefisien Determinasi}

Analisis koefisien determinasi dimaksudkan untuk mengetahui besarnya persentase pengaruh dari variabel independen terhadap variabel dependen baik secara parsial maupun simultan. Adapun hasil pengujian sebagai berikut:

Tabel 9. Hasil Pengujian Koefisien Determinasi Kualitas pelayanan Terhadap Kepuasan nasabah.

Model Summary

\begin{tabular}{|c|c|c|c|c|}
\hline Model & $\mathrm{R}$ & R Square & $\begin{array}{l}\text { Adjusted R } \\
\text { Square }\end{array}$ & $\begin{array}{l}\text { Std. Error of the } \\
\text { Estimate }\end{array}$ \\
\hline 1 & $.728^{\mathrm{a}}$ & .529 & .524 & 2.635 \\
\hline
\end{tabular}

a. Predictors: (Constant), Kualitas Pelayanan (X1)

Berdasarkan hasil pengujian diperoleh nilai determinasi sebesar 0,529 artinya kualitas pelayanan memiliki kontribusi pengaruh sebesar 52,9\% terhadap kepuasan nasabah.

Tabel 10. Hasil Pengujian Koefisien Determinasi Citra perusahaan Terhadap Kepuasan nasabah.

\section{Model Summary}

\begin{tabular}{lr|r|r|r} 
Model & R & \multicolumn{2}{c|}{$\begin{array}{c}\text { Adjusted R } \\
\text { Square }\end{array}$} & \multicolumn{2}{c}{$\begin{array}{c}\text { Std. Error of the } \\
\text { Estimate }\end{array}$} \\
\hline 1 & $.621^{\mathrm{a}}$ & .386 & .379 & 3.010 \\
\hline
\end{tabular}

a. Predictors: (Constant), Citra Perusahaan (X2)

Berdasarkan hasil pengujian diperoleh nilai determinasi sebesar 0,386 artinya citra perusahaan memiliki kontribusi pengaruh sebesar 38,6\% terhadap kepuasan nasabah.

Tabel 11. Hasil Pengujian Koefisien Determinasi Kualitas pelayanan dan Citra perusahaan Terhadap Kepuasan nasabah.

\section{Model Summary}

\begin{tabular}{|c|c|c|c|c|}
\hline Model & $\mathrm{R}$ & R Square & $\begin{array}{l}\text { Adjusted R } \\
\text { Square }\end{array}$ & $\begin{array}{l}\text { Std. Error of the } \\
\text { Estimate }\end{array}$ \\
\hline 1 & $.769^{\mathrm{a}}$ & .592 & .582 & 2.470 \\
\hline
\end{tabular}

a. Predictors: (Constant), Citra Perusahaan (X2), Kualitas Pelayanan (X1)

Berdasarkan hasil pengujian diperoleh nilai determinasi sebesar 0,592 artinya kualitas pelayanan dan citra perusahaan secara simultan memiliki kontribusi pengaruh sebesar 59,2\% terhadap kepuasan nasabah, sedangkan sisanya sebesar $47,1 \%$ dipengaruhi faktor lain. 


\section{d. Uji Hipotesis}

\section{Uji hipotesis Parsial (Uji t)}

Pengujian hipotesis dengan uji t digunakan untuk mengetahui hipotesis parsial mana yang diterima.

Hipotesis pertama: Terdapat pengaruh yang signifikan antara kualitas pelayanan terhadap kepuasan nasabah.

Tabel 12. Hasil Uji Hipotesis Kualitas pelayanan Terhadap Kepuasan nasabah.

\section{Coefficients $^{\mathbf{a}}$}

Unstandardized

Coefficients

\begin{tabular}{|c|c|c|c|c|c|}
\hline \multirow[b]{2}{*}{ Model } & \multicolumn{2}{|c|}{ Coefficients } & \multirow{2}{*}{$\begin{array}{c}\text { Coefficients } \\
\text { Beta }\end{array}$} & \multirow[b]{2}{*}{$\mathrm{t}$} & \multirow[b]{2}{*}{ Sig. } \\
\hline & $\mathrm{B}$ & Std. Error & & & \\
\hline 1 (Constant) & 13.455 & 2.565 & & 5.246 & .000 \\
\hline Kualitas Pelayanan (X1) & .653 & .067 & .728 & 9.721 & .000 \\
\hline
\end{tabular}

a. Dependent Variable: Kepuasan Nasabah (Y)

Berdasarkan hasil pengujian pada tabel di atas, diperoleh nilai t hitung $>\mathrm{t}$ tabel atau $(9,721>1,989)$, dengan demikian hipotesis pertama yang diajukan bahwa terdapat pengaruh yang signifikan atara kualitas pelayanan terhadap kepuasan nasabah diterima.

Tabel 13. Hasil Uji Hipotesis Citra perusahaan Terhadap Kepuasan nasabah.

\begin{tabular}{|c|c|c|c|c|c|c|}
\hline \multirow{3}{*}{\multicolumn{2}{|c|}{ Model }} & \multicolumn{2}{|c|}{ Coefficients $^{a}$} & \multirow[b]{2}{*}{$\begin{array}{l}\text { Standardized } \\
\text { Coefficients }\end{array}$} & \multirow[b]{3}{*}{$\mathrm{t}$} & \multirow[b]{3}{*}{ Sig. } \\
\hline & & \multicolumn{2}{|c|}{$\begin{array}{l}\text { Unstandardized } \\
\text { Coefficients }\end{array}$} & & & \\
\hline & & $\mathrm{B}$ & Std. Error & Beta & & \\
\hline \multirow[t]{2}{*}{1} & (Constant) & 15.154 & 3.192 & & 4.747 & .000 \\
\hline & Citra Perusahaan (X2) & .616 & .085 & .621 & 7.267 & .000 \\
\hline
\end{tabular}

a. Dependent Variable: Kepuasan Nasabah (Y)

Berdasarkan hasil pengujian pada tabel di atas, diperoleh nilai t hitung $>\mathrm{t}$ tabel atau $(7,267>1,989)$, dengan demikian hipotesis kedua yang diajukan bahwa terdapat pengaruh yang signifikan atara citra perusahaan terhadap kepuasan nasabah diterima.

\section{Uji Hipotesis Simultan (Uji F)}

Pengujian hipotesis dengan uji $\mathrm{F}$ digunakan untuk mengetahui hipotesis simultan yang mana yang diterima.

Hipotesis ketiga Terdapat pengaruh yang signifikan antara kualitas pelayanan dan citra perusahaan terhadap kepuasan nasabah.

Tabel 14. Hasil Uji Hipotesis Kualitas pelayanan dan Citra perusahaan Terhadap

Kepuasan nasabah.

\section{ANOVA ${ }^{a}$}

\begin{tabular}{ll|r|r|r|r|r}
\multicolumn{1}{l}{ Model } & Sum of Squares & \multicolumn{1}{c}{ df } & Mean Square & \multicolumn{1}{c}{ F } & \multicolumn{1}{c}{ Sig. } \\
\hline \multirow{2}{*}{1} & Regression & 733.085 & 2 & 366.542 & 60.093 & $.000^{\mathrm{b}}$ \\
\cline { 2 - 7 } & Residual & 506.264 & 83 & 6.100 & & \\
\cline { 2 - 7 } & Total & 1239.349 & 85 & & & \\
\hline
\end{tabular}

a. Dependent Variable: Kepuasan Nasabah (Y)

b. Predictors: (Constant), Citra Perusahaan (X2), Kualitas Pelayanan (X1)

Berdasarkan hasil pengujian pada tabel di atas, diperoleh nilai $\mathrm{F}$ hitung $>\mathrm{F}$ tabel atau $(60,093>2,710)$, dengan demikian hipotesis ketiga yang diajukan bahwa terdapat pengaruh yang signifikan atara kualitas pelayanan dan citra perusahaan terhadap kepuasan nasabah diterima. 


\section{Pembahasan Hasil Penelitian}

\section{Pengaruh Kualitas pelayanan Terhadap Kepuasan nasabah}

Kualitas pelayanan berpengaruh signifikan terhadap kepuasan nasabah dengan korelasi sebesar 0,728 atau memiliki hubungan yang kuat dengan kontribusi pengaruh sebesar 52,9\%. Pengujian hipotesis diperoleh nilai t hitung > t tabel atau (9,721 > 1,989). Dengan demikian hipotesis pertama yang diajukan bahwa terdapat berpengaruh signifikan antara kualitas pelayanan terhadap kepuasan nasabah diterima.

\section{Pengaruh Citra perusahaan Terhadap Kepuasan nasabah}

Citra perusahaan berpengaruh signifikan terhadap kepuasan nasabah dengan korelasi sebesar 0,621 atau memiliki hubungan yang kuat dengan kontribusi pengaruh sebesar 38,6\%. Pengujian hipotesis diperoleh nilai t hitung > t tabel atau (7,267 > 1,989). Dengan demikian hipotesis kedua yang diajukan bahwa terdapat berpengaruh signifikan antara citra perusahaan terhadap kepuasan nasabah diterima.

\section{Pengaruh Kualitas pelayanan dan Citra perusahaan Terhadap Kepuasan nasabah}

Kualitas pelayanan dan citra perusahaan berpengaruh signifikan terhadap kepuasan nasabah dengan diperoleh persamaan regresi $\mathrm{Y}=8,095+0,497 \mathrm{X} 1+$ $0,302 \mathrm{X} 2$, nilai korelasi sebesar 0,769 atau memiliki hubungan yang kuat dengan kontribusi pengaruh sebesar 59,2\% sedangkan sisanya sebesar $47,1 \%$ dipengaruhi faktor lain. Pengujian hipotesis diperoleh nilai F hitung $>\mathrm{F}$ tabel atau $(60,093>2,710)$. Dengan demikian hipotesis ketiga yang diajukan bahwa terdapat berpengaruh signifikan antara kualitas pelayanan dan citra perusahaan terhadap kepuasan nasabah diterima.

\section{KESIMPULAN DAN SARAN}

\section{Kesimpulan}

a. Kualitas pelayanan berpengaruh signifikan terhadap kepuasan nasabah dengan kontribusi pengaruh sebesar 52,9\%. Uji hipotesis diperoleh nilai $t$ hitung $>t$ tabel atau $(9,721>1,989)$.

b. Citra perusahaan berpengaruh signifikan terhadap kepuasan nasabah dengan kontribusi pengaruh sebesar 38,6\%. Uji hipotesis diperoleh nilai t hitung $>\mathrm{t}$ tabel atau $(7,267>1,989)$.

c. Kualitas pelayanan dan citra perusahaan berpengaruh signifikan terhadap kepuasan nasabah dengan kontribusi pengaruh sebesar 59,2\% sedangkan sisanya sebesar 47,1\% dipengaruhi faktor lain. Uji hipotesis diperoleh nilai $\mathrm{F}$ hitung $>\mathrm{F}$ tabel atau $(60,093>$ 2,710).

\section{Saran}

a. Variabel Kualitas pelayanan, 519ariable519 yang paling lemah adalah tangible. Untuk lebih baik lagi perusahaan perlu memperkuat kelengkapan sarana dan prasarana mengingat sarana prasarana sebagai alatn penunjang pelayanan nasabah memiliki peranan yang penting dalam memaksimalkan pelayanan yang optimal harus mendapatkan prioritas sehingga bank semakin memiliki kinerja yang lebih baik.

b. Variabel Citra perusahaan, 519ariable519 yang paling lemah adalah disukai (Likeability). Untuk lebih baik lagi perusahaan harus memperbaiki kemampuan karyawan terkait kemampuannya mengingat citra perusahaan terbentuk dari banyak hal. Hal-hal positif yang dapat meningkatkan citra suatu perusahaan misalnya: sejarah atau riwayat hidup perusahaan yang gemilang, keberhasilan di bidang keuangan yang 
diraih-nya, hubungan industri yang baik, reputasi sebagai pencipta lapangan kerja dalam jumlah besar, keberhasilan tanggung jawab sosial, komitmen mengadakan riset, dan lainnya maka perusahaan sebaiknya bersinergi dengan seluruh sumberdaya yang dimiliki agar citra perusahaan dapat semakin baik sebagai kesan keseluruhan yang muncul dalam pikiran masyarakat

c. Variabel kepuasan nasabah, 520ariable520 yang paling lemah adalah memenuhi kebutuhan. Untuk lebih baik lagi perusahaan harus aktif menginventarisir produk layanan dan kebutuhan nasabah yang kedepan dikehendaki sehingga perusahaan dapat menyediakan sesuai yang dibutuhkan mengingat ketidakpuasan terjadi manakala nasabah telah menggunakan produk atau jasa bank dan merasakan bahwa kinerja ternyata tidak memenuhi harapan, ketidak puasan bisa menimbulkan sikap 520ariable terhadap bank itu sendiri, dengan demikian perusahaan harus berusaha agar dapat memenuhi harapan dan keinginan nasabah agar dapat mencapai kepuasan yang optimal.

d. Kontibusi pengaruh 520ariable bebas terhadap 520ariable terikat sebesar 53\%, nilai ini masih 520ari ditingkatkan dengan secara selektif dapat memprioritaskan layanan nasabah yang harus dipenuhi dan kondisi masing-masing 520ariable bebas harus ditingkatkan secara signifikan. Oleh karenanya disarankan kepada penelitian berikutnya agar melakukan penelitian yang relevan dengan cara memperbaiki 520ariable520 yang masih tidak baik atau dengan menambah 520ariable520 pertanyaan dan jumlah responden penelitian sehingga akan dapat lebih diketahui 520ariable yang paling memberikan kontribusi positif bagi perusahaan.

\section{DAFTAR PUSTAKA}

Algifari, Analisis Regresi, Yogyakarta, 2014.

Alma, Buchori, Manajemen Pemasaran \& Pemasaran Jasa, CV. Alfabetha, Bandung, 2014.

Anaroga, Panji, Mananajemen Bisnis, PT. Rineka Cipta, Semarang, 2011.

Arikunto, Suharsimi, Prosedur Penelitian Suatu Pendekatan Praktek, PT. Rineka Cipta, Jakarta, 2015.

Erlangga, H. (2021). Effect Of Digital Marketing And Social Media On Purchase Intention Of Smes Food Products. Turkish Journal of Computer and Mathematics Education (TURCOMAT), 12(3), 3672-3678.

Ferrinadewi, Erna, “Merek Dan Psikologi Konsumen”, Graha Ilmu, Yogyakarta, 2012.

Ghozali, Imam, "Aplikasi Analisis Multivariate dengan Program SPSS”, Edisi Kelima, Badan Penerbit Undip, Semarang, 2014.

Haque, M. G., Munawaroh, M., Sunarsi, D., \& Baharuddin, A. (2021). Competitive Advantage in Cost Leadership and Differentiation of SMEs "Bakoel Zee" Marketing Strategy in BSD. PINISI Discretion Review, 4(2), 277-284.

Husen, Umar, "Riset Pemasaran Dan Perilaku Konsumen”, PT. Gramedia Pustaka Utama, Jakarta, 2013.

Inpres No.6/2014, tentang peningkatan daya saing menghadapi Masyarakat Ekonomi ASEAN.

Irawan, Handi, "Prinsip-Prinsip kepuasan nasabah”, PT. Alex Media Komputindo, Jakarta, 2014.

Jasmani, J., Sutiman, S., \& Sunarsi, D. (2020). Analysis of the Effect of Prices, Promotions and Products on Purchase Interest Impacts on Consumer Satisfaction of VIVO Brand Mobile Phones in South Tangerang Region. Jurnal Ad'ministrare, 7(1), 73-82. 
Kadarusman, Y., \& Sunarsi, D. (2020). Pengaruh Strategi Penetapan Harga Terhadap Peningkatan Jumlah Siswa Pada SMK PGRI Balaraja. JS (Jurnal Sekolah), 4(3), 213-221.

Keller dan Amstrong, "Prinsip-prinsip Pemasaran”, Edisi Kedua Belas, Jilid Satu, Erlangga, Jakarta, 2014.

Keputusan Presiden No.37/2014 tentang regulasi pemerintah dalam upaya untuk meningkatkan daya saing nasional dan menghadapi MEA.

Kotler dan Keller, “Manajemen Pemasaran”, Edisi Kedua Belas, Jilid Satu, Erlangga, Jakarta, 2014.

Kotler"Manajemen Pemasaran”, Edisi Keempat belas, PT. Indeks, Jakarta, 2014.

Laksana, Fajar, “Manajemen Pemasaran”, Edisi Pertama, Graha Ilmu, Yogyakarta, 2014

Lupiyoadi, ”Manajemen Pemasaran Jasa”, Edisi 3, Salemba Empat, Jakarta, 2014.

Macaulay, Steve \& Cook, Sarah. How to Improve Your Customer Service. Jakarta: Gramedia Pustaka Utama, 2014.

Nurjaya, N., Affandi, A., Erlangga, H., Sunarsi, D., \& Jasmani, J. (2021). The Effect of Product Promotion and Innovation Activities on Marketing Performance in Middle Small Micro Enterprises in Cianjur. Budapest International Research and Critics Institute (BIRCI-Journal): Humanities and Social Sciences, 4(1), 528-540.

Ratih Huriyati. Bauran Pemasaran dan Loyalitas Konsumen. Alfabeta,.Bandung, 2014.

Safroni, Ladzi, "Manajemen dan Reformasi Pelayanan Publik dalam Konteks Birokrasi Indonesia”, Aditya Media Publishing, Surabaya 2012.

Santoso, Singgih, "SPSS Statistik Parametik” Cetakan Kedua, PT. Elek Media, 2015.

Sarwono, Jonathan, "Metode Penelitian Kuantitatif Dan Kualitatif", Graha Ilmu, Yogyakarta, 2012

Simamora, Bilson, "Panduan Riset Dan Perilaku Konsumen”, PT. Gramedia Pustaka Utama, Jakarta, 2013.

Stanton, William J. 2013. Prinsip Pemasaran . Alih Bahasa oleh Sadu Sundaru. Jilid Satu. Edisi Kesepuluh.Erlangga, Jakarta, 2013.

Sudjana, "Metode Statistika", Edisi Keenam, Tarsito, Bandung, 2011.

Sugiyono, "Metode Penelitian Kuantitatif Kualitatif dan R \& D", Penerbit CV. Alfabeta, Bandung, 2014.

Suherman, Wawan, "Kurikulum Berbasis Kompetensi Pendidikan Jasmani Teori dan Praktik Pengembangan", FIK UNY, Yogyakarta, 2012

Sunarsi, D. (2020). Pengaruh Bauran Pemasaran Dan Kualitas Pelayanan Terhadap Kepuasan Konsumen Pada Giant Dept Store Cabang BSD Tangerang. E-Mabis: Jurnal Ekonomi Manajemen dan Bisnis, 21(1), 7-13.

Supranto, "Statistik Teori dan Aplikasi", Pustaka Ekonomi, Jakarta, 2013.

Swastha, Bashu dan T. Handoko, "Manajemen Pemasaran Moderen”, BPFE, Yogyakarta, 2013.

Tasunar, Nanang, "Citra perusahaan”, Gramedia Pustaka Utama, Ghalia Indonesia, Bogor, 2012.

Tjiptono, Fandy dan Gregorius Chandra, "Serivce Quality and Satisfiation”, Edisi tiga, Andi, Jakarta, 2014.

Undang-Undang Perbankan No.10 Tahun 1998 Tentang Badan Usaha Penghimpun Dana Masyarakat dan Perlindungan Nasabah.

Yazid, "Pemasaran Jasa, Konsep dan Implementasi", Edisi Kedua, PT. Ekonisia, Yogyakarta. 2015. 